\title{
Sacramental view of creation: Denis Edwards on God's presence in natural world
}

\begin{tabular}{|c|c|}
\hline $\begin{array}{l}\text { Author: } \\
\text { Piotr Roszak }\end{array}$ & \\
\hline $\begin{array}{l}\text { Affiliations: } \\
{ }^{1} \text { Department } \\
\text { Philosophy, Fa } \\
\text { Theology, Nicc } \\
\text { University, Tor }\end{array}$ & $\begin{array}{l}\text { f Christian } \\
\text { culty of } \\
\text { laus Copernicus } \\
\text { uń, Poland }\end{array}$ \\
\hline $\begin{array}{l}{ }^{2} \text { Faculty of Th } \\
\text { Universidad d } \\
\text { Pamplona, Sp }\end{array}$ & $\begin{array}{l}\text { eology, } \\
\text { e Navarra, } \\
\text { ain }\end{array}$ \\
\hline $\begin{array}{l}{ }^{3} \text { Department } \\
\text { and Historical } \\
\text { Faculty of The } \\
\text { Religion, Univ } \\
\text { Pretoria, Pret } \\
\text { South Africa }\end{array}$ & $\begin{array}{l}\text { of Systematic } \\
\text { Theology, } \\
\text { ology and } \\
\text { ersity of } \\
\text { oria, }\end{array}$ \\
\hline $\begin{array}{l}\text { Research Proj } \\
\text { Project Leade } \\
\text { Project Numb }\end{array}$ & $\begin{array}{l}\text { ect Registration: } \\
\text { r: J. Buitendag (D) } \\
\text { er: } 2402343\end{array}$ \\
\hline $\begin{array}{l}\text { Description: } \\
\text { This research } \\
\text { the research } \\
\text { 'Understandir } \\
\text { (Theology anc } \\
\text { directed by Pr } \\
\text { Buitendag, De } \\
\text { Systematic an } \\
\text { Theology, Fac } \\
\text { and Religion, } \\
\text { Pretoria. }\end{array}$ & $\begin{array}{l}\text { is part of } \\
\text { project } \\
\text { g Reality } \\
\text { Nature)', } \\
\text { of. Dr Johan } \\
\text { partment of } \\
\text { d Historical } \\
\text { ulty of Theology } \\
\text { University of }\end{array}$ \\
\hline $\begin{array}{l}\text { Correspondin } \\
\text { Piotr Roszak, } \\
\text { piotrroszak@ }\end{array}$ & $\begin{array}{l}\text { g author: } \\
\text { umk.pl }\end{array}$ \\
\hline $\begin{array}{l}\text { Dates: } \\
\text { Received: } 28 \\
\text { Accepted: } 14 \\
\text { Published: } 15\end{array}$ & $\begin{array}{l}\text { Mar. } 2021 \\
\text { May } 2021 \\
\text { July } 2021\end{array}$ \\
\hline $\begin{array}{l}\text { How to cite th } \\
\text { Roszak, P., } 20 \\
\text { view of creati } \\
\text { Edwards on G } \\
\text { in natural wor } \\
\text { Teologiese Stu } \\
\text { Theological St } \\
\text { a6669. https:/ } \\
\text { org/10.4102/ }\end{array}$ & $\begin{array}{l}\text { is article: } \\
\text { 21, 'Sacramental } \\
\text { on: Denis } \\
\text { od's presence } \\
\text { Id', HTS } \\
\text { Idies/ } \\
\text { udies 77(3), } \\
\text { /doi. } \\
\text { hts.v77i3.6669 }\end{array}$ \\
\hline Read online: & \\
\hline 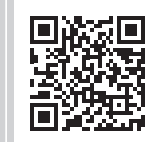 & $\begin{array}{l}\text { Scan this QR } \\
\text { code with your } \\
\text { smart phone or } \\
\text { mobile device } \\
\text { to read online. }\end{array}$ \\
\hline
\end{tabular}

This review article summarises and engages critically with two books published by ATF Press in 2017 and 2020. One of them is Denis Edwards's book that reflects his theological approach to nature, divine action and environmental ethics. The second book is a series of papers inspired by his theological approach. The great merit consists of establishing a fresh meaning of nature from the theological perspective. The article gathers three main themes present in the book: the meaning of nature, the inclusive character of the theology of nature and the relationship between God and nature from the Trinitarian perspective.

Contribution: The purpose of this article is to demonstrate the recent development of the theology of nature and the share Denis Edwards had in it. The theology of nature needs to be 'extended' in order not just to include the relationship between the human and God, but the goal of the entire creation, and to point to the theological reasons for such an approach.

Keywords: divine action; sacraments; theology of nature; Thomism; ecotheology.

\section{Introduction}

As part of the dialogue between religion and science, there has recently been a talk about a 'theological turn', which is manifested, among others, in the theological reflection on nature and in a broader sense than before, Trinitarian approach to God's action (Ritchie 2017:361379). The concept of nature and what is natural has gone through a long process of historical reflection, providing a reference point for the reflection on grace, miracles perceived dialectically in relation to nature, to the naturalisation of grace. This dominant image of nature, reinforced by a mechanistic approach, in which it was deprived of self-determination proper to the Thomistic view, was reduced to being a passive instrument of other forces. There was, however, a lack of a modernised theological reflection on nature in the context of scientific achievements as such. The answer to the question whether it has its own value or a dependent (functional) is relevant to topics related to the theology of nature, which, although present in the theological tradition, did not occupy their proper place. The theology of nature needs to be 'extended' in order to include not just the relationship between the human and God but also the goal of the entire creation and to point to the theological reasons for such an approach.

There are two publications that bind the person of Denis Edwards (1943-2019), an Australian theologian who developed theology of nature from a systematic perspective, with the attempt of gathering the efforts of recent years in the theology of nature.

The first one is a set of essays written by authors from many Christian denominations, collected by Ted Peters and Marie Turner (Peters \& Turner 2020a). It is a book that has been included in a specific structure of 'from - to' that reflects Edwards' theological thinking: from God to nature, from deep incarnation to deep divinisation, from Evolution through the Eucharist to Ecology, from Spirit to Life and from Deep Crucifixion to Deep Resurrection. This calls to mind the classic exit-return (exitus-reditus) scheme on which the Summa Theologiae is based, whereas in Edwards' case - a methodological perspective: it considers nature from the perspective of the place it holds in God's plan. This specific symphony of many views is a perfect reflection of the setting of new directions for theology of nature rather than the state of the discussion on its regard. The theological reflection on the importance of nature takes place in a situation of increasing knowledge about it on the part of sciences, in particular biology and physics (Oleksowicz 2020; Sánchez-Palencia \& Jordana-Butticaz 2021), but the reception is not a

Copyright: ( 2021. The Authors. Licensee: AOSIS. This work is licensed under the Creative Commons Attribution License. Note: Special Collection: Theology and Nature, sub-edited by Johan Buitendag (University of Pretoria). 
scientistic adjustment of theology to science, but the acceptance of inspiration and questions in the spirit of understanding theology as a discourse revealing the whole, that is, in a top-down perspective.

The second book is a set of texts by Denis Edwards himself (Edwards 2017), collected thematically and comprising issues of divine action, the theology of nature and its theological inspirations, both historical (Athanasius, Aquinas, Bonaventure, Duns Scotus) and modern (Rahner \& De Chardin). Edwards has what every theologian should: to stand on the shoulders of great authors and look at the current situation, without fear of pointing to the practical aspects of theology. Incarnation and its range are at the centre, with its significance for life - because it was an event aimed at the future, it thereby brings an inclusive approach (all creation will experience salvation). Nevertheless, both books represent an essential part of Edwards' theological potrait of nature which he did not understand statically, but in span - for creation does not only comprise of what it currently is but also comprise of what it can become.

From a methodological point of view, with such a wide theme covered in both books, it is worth focusing on one key issue, which, in my opinion, is the 'sacramentality' of nature, that provides a framework and key to the explanation of why nature is at the recentre of interest (deep incarnation), and also on the focus of theological interest on the world (divinisation). It will be a duet in which Edwards' thinking meets the 'echo' of other thinkers, gathered in the second volume edited by Peters and Turner, who he does not regard as 'sources', even though they are inspiring interlocutors, but only explores them.

The purpose of this review article is to demonstrate the recent development of the theology of nature and the share Denis Edwards had in it. It consists, inter alia, in the significant development of the idea of sacramentality - present in 20thcentury theology, among others in Karl Rahner, Joseph Ratzinger or Johannes Pinsk - by indicating its new dimensions, especially the transition from physicalism, which perceives the human as a passive recipient of grace, to personalism, in which grace and freedom are not dialectically represented. The theological approach to nature can be built on an integral vision of nature, in which the human is not considered in abstraction from nature, but in discovering connections and relationships with all nature. This fits perfectly into a new scientific paradigm that departs from the pyramidal recognition of the relationship between different sciences in favour of a network model (Sanchez-Cañizares 2019). In this approach, what counts are the connections and nodes established by individual sciences, which open them up to each other.

\section{Why does nature matter in theology?}

Contemporary literature on the theology of nature and sacramentality experiences a revival in various theological traditions, in the Orthodox, Protestant and Catholic thought.
In the case of sacramentality, the efforts of the existing theology directed its attention on the apologetics of the sacraments, their understanding and justification, but at the same time the conviction about the need of broadening the understanding of sacramentality as a basis for sacramental signs does not return eagerly. Such a framework allows to look on soteriology from a different perspective, in which many signs (not just seven) can have a saving nature. Patristic and early medieval theology listed more than seven sacraments, for example, St. Augustine enumerated 304 of them, and Bernard of Clairvaux explained that an hour is not enough to name them all, and the sacred-profane relationship undergoes a significant reformulation.

Ecotheologies are the basis for not only expressing concern for the world but also admonishing about the forgotten inclusion of nature in theological reflection. There is a tendency of 'skipping' and ignoring 'nature', which becomes merely a setting for events in the history of salvation. It is not about the moral aspects of degradation of the planet, but about the promotion of pro-ecological behaviour, and Edwards and the authors of Peters and Turner's volume are aware that this attitude is because of theological negligence. Usually, great social changes began with a change in theology (Milbank 2006), but also at some theological cost: in the case of ecotheology, there were trends suggesting the necessity of rejecting transcendence as a certain reaction to the earlier omission of the subject (George 2019). It seems, however, on the basis of a pendulum, that overemphasis does not bring anything out of the ordinary.

This naturalness of nature, however, does not have an exclusive character, which over time in the context of Enlightenment has become part of philosophy, as an exclusionary God, or in radical forms of process theology identifying God with immanent processes. Edwards was able to pass between Charybdis and Scylla by drawing inspiration and avoiding extremes. Theology always falls within the worldview, expanding and purifying, but never trying to create a world of its own. Whereas the key was to relate to a new model of the nature of theological truths, this seems to be one of the great merits of Denis Edwards. A new comprehension of nature, that recognises the dynamism of creative novelty in it, has revolutionised the thinking of the philosophy of nature. Unfortunately, theology has remained with the old and operates a static concept in its discourse, incompatible with the scientific framework, which indicates that the dialogue of these approaches is at risk of building two different worlds.

\section{The meaning of nature: Evil, evolution and divine goodness}

Edwards is convinced that the fundamental nature of reality is relational, mutually responsible and oriented to love. For this reason, he is in favour of seeing the Church as a 'sacrament of relationship', and in this key, he actually 
reads the issues of the relationship between evolution and theology (Whitfield 2020).

In this context, Ilia Delio is considering relational holism more broadly in the perspective of the discovery of modern physics, such as the electron whose characteristics are all affected by relationships. It calls to mind Pierre T. de Chardin and his understanding of relationality as the principle of being, and at the same time a path to more being and more life, which are inscribed in creation and attainable through relationships. She considers the faces of contemporary monism in the context of consciousness and material world relations as overcoming the Kantian paradigm. Still, its task is to show the impact that de Chardin has on the evolutionary and ecological theology of Denis Edwards. At the same time, orientation towards the future builds a very practical 'morality of involvement' (Delio 2020:191).

The value of nature is not 'functionalistic' but internal, which is why deep incarnation is to speak in favour of the logic and connectivity of God's salvific action, which in the case of incarnation is not a plan B. In my opinion, this point seems to be particularly important, because many theological problems with nature involve narrowing the interpretive horizon that falls into the range between creation and redemption. After all, creation is a work of mercy situated in the perspective of a meta-settlement of why there is a world at all. With this approach, the eschatology of nature in Edwards' treatise does not signify God's intervention from the outside, but the intensifications through the victory of Christ, the immanent presence by the virtue of creation (Roszak \& Huzarek 2019:740).

\section{The inclusive theology of nature}

Theology of nature, understood in the key to deep incarnation, wants to recall the fundamental relationship of God to his creation, and the human cannot be considered in isolation from this context. After all, the whole creation participates in this divine plan, but not in the same way, as Nesteruk rightly observes (Nesteruk 2020:84), and this appears to be a thesis with which Edwards - familiar with Aquinas - would agree, for the concept of order of creation (ordo creationis) does not signify equality, but respect for the diversity of creation. The key, however, is a renewed notion of nature, which is not to be understood as a mere setting in which we live, as we are part of a nature which remains in interaction (Downs 2020:144). In considering nature, an inclusive approach is needed rather than an exclusive one: including the whole created world in God's saving care, though this view is often absolutised, it is recognised to the same extent that it is equal.

Hence, within the theology of nature, the question concerning human uniqueness on the background of nature arises: are we one member alongside others in the earthly community or are we endowed with the unique gift of 'being the image of God' (Schoot 2020), who for this reason is to be the guardian of the rest of the creatures and lead them to wholeness? Mark Worthing draws attention to this aspect by correctly noting that the account from the Book of Genesis emphasises the interconnectedness of all creation, which was made of the dust of the ground and is described as a living soul, which today finds its expression in the fact that all living things share the same building blocks of DNA. For Worthing, the difference as to intelligence is the difference of degree, not kind. In this context, Nesteruk warns against equating humans with other creatures, recalling a crucial patristic inspiration of perceiving the world as macroAnthropos rather than micro-Logos, and this means understanding humanity as a hypostasis of the universe (which medieval theology will later develop in the vision of the human as a microcosmos). Nesteruk, in presenting his four objections to the idea of deep incarnation, simultaneously indicates further directions of the development of this idea, so that it would be a necessary condition for incarnation and lead to reflection on the mediating agency of humanity within creation and in the relations of creation to God. Nesteruk's methodological objections are an indication of a certain threshold that must be crossed in order not to remain in a shallow, reductionist naturalism but to behold something more in the complicated picture.

Following Rahner, the value of nature consists in the fact that temporal history of the creature's world, its material dimension, as Ted Peters concludes (Peters 2020:134), becomes the medium through which the persons of the Holy Trinity relate to one another as perichoresis. Nonetheless, this understanding of the Trinitarian nature of God opens up a thinking about relationality and leads to Spirit Christology, as Julie Trinidad notes. The Spirit shows that God's love is not self-contained (Trinidad 2020:274), it is rather characterised by vulnerability, and that creation encourages humans to contribute to self-transcendence. Interestingly, it is this theology of the Spirit that Celia Deane-Drummond finds the most necessary for a proper narrative about the sacred in the natural world (Deane-Drummond 2020:286). Spirit is the immanent presence of God in creation, which must be written into the scientific understanding of the evolution of life (Strumiłowski 2019).

\section{The Christological ground of nature}

The picture of modern trends in the development of the theology of nature would, however, not be complete if it were to remain only in its inclusive character, which derives from the truth about creation, but does not consider the new relationship to creation that flows from the incarnation of Christ. Edwards' reflection on the theology of nature reveals his deep incarnation Christology, where his understanding of 'deep' is what draws the most attention. The authors of the reflections on this subject seek to grasp the implications of applying this principle of incarnation to the theology of nature. Nesteruk pointed out that this depth is not only about creating conditions that are necessary for the incarnation (to have something to take the body from), but in the fact that the whole world with its history is shaped by the creative acts of God in such a way that the incarnation could take place (Nesteruk 2020:86). But also, God's descent into the pain and 
suffering of creation has its part in this, as Worthing emphasised, and thereby dignifies the physical (Worthing 2020:96). The whole creation was incorporated through the body assumed in a hypostatic union, and therefore, the mystery of incarnation can no longer be understood in terms of a merely divine-human relationship.

Joseph E. Lenow points to three possible directions for extending deep incarnation, by mentioning ecojustice, which highlights that every creature has its value and purpose in creation; stewardship as a covenantal grace, which consists in bringing the natural world into this covenant (Alvarado 2020); and ecological spirituality based on theosis. This signifies that it is about a profound transformation, first and foremost, in our thinking about how life in Christ, the essence of Christian life, connects us with the natural world (Lenow 2020:322). Meanwhile, Stephen Downs discerns deep incarnation as a departure to a 'zoo-centric thinking', which, in his opinion, arose from reading the Book of Genesis in the spirit of the dominion model. Still, even the stewardship model has its limitations and therefore suggests a creationcentred or eco-centric model.

Ted Peters takes a step further in his illuminative essay and shows the implications of the idea of deep incarnation for extra-terrestrial life. The rule of his thinking is the communicatio idiomatum principle on the basis of which the relationship between the human and divine nature in the person of the Word becomes a mutual exchange (allowing for a specific mode of theological judgement). Therefore, through Christ, the suffering of God with his creation becomes part of the perichoresis of the Trinity. This signifies that what was assumed in the incarnation - human nature becomes incorporated into Trinitarian life, consisting in the perichoresis of Persons: it is now extended to include creation. Such an image of the meaning of salvation, exceeding the juridical approach, was presented by the theology of the New Testament, in which the human being, because of the incarnation of the word, becomes 'a participant in the divine nature'. The incarnation reaches the tiniest living creatures, because this incarnate presence means being related to the whole of universe, for the reception of the body is never detached from its relation to the environment. This is where a perspective opens up for astrotheology and for answering the dilemmas of transhumanism with the idea of disembodied intelligence, which at first glance seems to reject the postulate of deep incarnation (Peters 2019). Peters, however, posits the thesis that every life in the creaturely world is received in the body of the Logos.

A valuable development of the theology of nature proposed in the publication on Denis Edwards is the inclusion of the Eucharist in these reflections. It is Jamie L. Fowler who takes up the Eucharistic implications of deep incarnation, as the presence of the risen body of Christ in this sacrament is related to matter, the fruit of the earth and the work of the hands, and thus, in using the term of Paul Tillich, enters into the multidimensional unity of life through incarnation. This establishes the relationship between the divine and material reality, but in this chapter the attempts of juxtaposing Edwards with Tillich are apparent: the fruit is an indication of the self-giving nature of God (Fowler 2020:210) and the degree of intimacy with us in the Eucharist. As risen and present in the sacrament, he becomes the ultimate dimension that envelops all material components of reality. If bread and wine are the matter of presence, inorganic material, then it is evident that God's presence is related to many dimensions of reality. This very process has been called by Anthony J. Kelly 'The Christening of the Universe' (Kelly 2020:218) which thus, by acting as an all-unifying attractor, causes all life forms to be embodied in his risen body. Therefore, the Eucharist is a celebration of the sacredness and wholeness of creation, and for this reason, it is ecological and cosmic.

Another dimension of the theology of the Eucharist, built on deep incarnation, is highlighted by Mary E. McGann, who emphasises hospitality and justice, achieved through the unity of creatures gathering at the table of God. It is the link between the body of Christ, who by the power of the Spirit is present in sacramental forms. The body present in the world, for, as the liturgical anamnesis indicates that Jesus entered the interdependent web of life (McGann 2020:235) through the incarnation, revealing divine mercy and sanctifying both individual lives and their interconnections. A reference to the medieval inversion in the understanding of the 'mystical body' and the 'real body', as noted and described by $\mathrm{H}$. de Lubac in one of his books, could certainly broaden this perspective even further.

\section{Sacramental view of nature}

In the theology of nature, many authors make an important breakthrough approach of transgression, which sees this sacramentality mainly in 'good' situations; meanwhile, suffering has a sacramental dimension as well. The sacramentality of nature thus consists in the fact that being a cruciform in the pain and decay of creation, the presence of Christ is being revealed, creation and incarnation together, and the eschatological future included. To think about nature in a sacramental way is to grasp the whole, the sign and its meaning, rather than focusing on one dimension. It seems, although the authors of the texts did not do it in a systematic way, that in the case of contemporary reflections on sacramentality, this term should be read in a threefold key: as a revelation, thus making the knowledge about God available which is inaccessible at the level of nature itself; transcendence by reference to the divine exemplar and unification, because a sacrament is a tool for uniting and unifying people with God, bringing into communion with the Creator and Redeemer (Roszak 2017:145). What, then does sacramental thinking about nature bring? This is a background that allows us to grasp the value of the created world. Contrary to the difference or distance emphasised in sacramentality, creation and incarnation do show God's relationship with creation. In this sense, a key wording emerges about the 'sacramental potential of nature' in 
its power to express God, although it is worthwhile not to lose sight of the distinction between omnipresent and omnimanifest (Gregersen 2020:28).

\section{Thomistic background of the theology of nature}

Undoubtedly, the Thomistic roots of Edwards' thought are visible in a material way (through direct references to the works of Aquinas) as well as in a formal way when the Thomistic way of thinking is revealed. This can be seen both in the theme of divine action in the world and in recognising the potential of the Thomistic understanding of nature, which lacks the modern static and person-nature dichotomy (Marcos \& Perez 2018:8). St. Thomas emphasised in his Commentary on the Letter to the Romans that everything God does is natural. Then, it is natural for God to perform the resurrection of a dead person or restore the sight of a blind person, because he is the creator of nature.

Various criticisms have been raised against the Thomistic model advocated by Edwards, particularly such that the distinction between first cause and secondary causes really adds nothing. Somewhat surprising - because unfairly critical - is the criticism of Aquinas carried out by J. Haught in this regard (Haught 2020:160). He claimed that for Aquinas, incarnation is 'predominantly as an expiation for $\mathrm{sin}^{\prime}$, and yet, this is not the context of Aquinas, but of later eras. Aquinas indicated a number of reasons for the incarnation. In the case of the Summa contra Gentiles, only two out of eight reasons relate to human sin, because St. Thomas sets everything on the human's pursuit of happiness, in which the incarnation is helpful. Besides, Haught believes that both Rahner and Edwards did not abandon the Thomistic description of the world (as de Chardin did), on account of a certain 'sense of obligation to the Roman Catholic Thomistic turn' in the early 20th century, and that leads to a cautious theology. However, it is difficult to treat this as a justified argument because it echoes an unproven accusation about the lack of theological independence, which, with the bold claims of Edwards and Rahner, is quite incomprehensible. According to Haught, the invocation of first and second causality prevents Edwards from fully responding to contemporary scientific challenges. The objection is the clinging to the immobile metaphysics of being, that fails to render the world in process and becoming, rather than on uniri - proper to Teilhard. Such thinking, though, seems to be a simplification. Becoming has already been described in classical metaphysics, and paradoxically, many neo-Aristotelian publications tend to return to attractive formulations of this thinking, whereas the exclusive preoccupation of being does not mean codification. Haught discerns, however, that in Edwards' case, apart from a shift of language, there is a leaning towards the future rather than a focusing on a fixed past, which shapes his approach to evolution and the novelty that appears along the way.
Another author, Joseph Backen, wonders to what extent Edwards has succeeded in bringing together what he believes are distant systems of the Neoplatonic Athanasius and the Thomistic Rahner, of which the former emphasises the transcendence and the latter the immanence of God in creation. Still, this is not a reproach but a demonstration of some of the dilemmas of contemporary theology of science, in which the challenge is to reconcile category and approach to reality, by classical metaphysics and empirically oriented natural science, based on making hypotheses and verifying them. Sometimes, the temptation is to stay at the level of Scripture metaphors instead of putting theorems about God into the context of a worldview established by science. Bracken's original proposal is a system-oriented Trinitarian theology (Bracken 2020:305) that would attempt to inscribe the truth about God in a system theory rather than in substantial metaphysics, because as he notes, the Christian God can be described in these categories as a community or corporate unit of dynamically interrelated parts or members. This allows the question of panentheism to be framed in analogy to the scientific explication: as a minisystem like an atom does not lose its functions when becoming something larger, for instance, a molecule, and this molecule does not lose its specific identity when becoming part of a cell - then, it is proper to speak about creatures existing in God in an analogous way.

\section{Concluding remarks}

What we owe to others in the intellectual reflection can only be seen from a certain perspective. The same applies to reflections on the theology of nature, creatively undertaken by Denis Edwards and others, whose texts have been collected in the discussed book. Thanks to this, we have the opportunity of seeing a multifaceted group which has contributed to reclaiming the topic of nature and taking it out of the framework in which it has hitherto operated, rather than scattered philosophers and theologians who reflect on other topics. These are not easy processes, because established approaches and habits seem merely to address repetition and not exploration.

The merit of Edwards and other authors is thus the return to the understanding of nature that existed in classical theology, but allergic reactions appeared out of fear of distortion. Today, the objection of naturalism in its radical form seems to prevent it from its creative continuity. The contribution can be considered on several levels, of which I would mention the three primaries.

The first point focuses the attention on inclusivity and relationality, the exceedance of a mechanistic worldview, grounded on Cartesian and Lockean dualism, characterised by a reductionist and objectifying approach and the shift to an integral or holistic perspective, highlighting the idea of unity, communication between the parts of nature, coresponsibility and relationality (Jennings 2019:247-266).

Furthermore, this signifies the theological approach to the theology of nature, and particularly the Trinitarian nature of 
divine action: Edwards does not want to place these considerations on one plane but deliberately overlaps the maps - philosophical, Trinitarian, ecological, and it turns out to be coherent. It is difficult to practice theology in closed treaties, without a Christological, and therefore Trinitarian, axis. This should not be at the expense of resigning from theology, but of a greater saturation of the studied topics with theology.

The third aspect includes placing the theology of nature in the right context created by modern science. That is why, the considerations are being made in view of the challenges posed by the theory of evolution to theodicy, the scientific data on the climate, the future of the universe and also the discoveries of modern physics.

I am convinced that the writings of Edwards and the leading theologians of nature, compiled in a book edited by Peters and Turner, will set a certain methodological reference in further research on nature from a theological perspective. But this will also be a form of theological renewal through a bold seeking of answers in the light of the best theological solutions. The example of using Thomism and its intuition is paradigmatic. That way, we are gaining a meta-perspective for the reflection on nature, which consists in the process of reconciling everything in Christ (cf. 2 Cor 5:19).

\section{Acknowledgements}

The author acknowledges Dorota Adamiec for English editing.

\section{Competing interests}

The author declares that he has no financial or personal relationships that may have inappropriately influenced him in writing this article.

\section{Author's contributions}

P.R. is the sole author of this research article.

\section{Ethical considerations}

This article followed all ethical standards for research without direct contact with human or animal subjects.

\section{Funding information}

This research received no specific grant from any funding agency in the public, commercial or not-for-profit sectors.

\section{Data availability}

Data sharing is not applicable to this article as no new data were created or analysed in this study.

\section{Disclaimer}

The views and opinions expressed in this article are those of the author and do not necessarily reflect of the official policy or position of any affiliated agency of the author.

\section{References}

Alvarado, R., 2020, A theology of nature, Wordbridge, Aalten.

Bracken, J.A., 2020, 'In dialogue: Athanasius, Ranher and Edwards on the Trinity', in T. Peters \& M. Turner (eds.), God in natural worlds. Theological explorations in appreciation of Denis Edwards, pp. 297-312, ATF, Adelaide.

Deane-Drummond, C., 2020, 'The spirit of life in a scientific age: Towards a Sophianic pneumatology in dialogue with Denis Edwards', in T. Peters \& M. Turner (eds.) God in natural worlds. Theological explorations in appreciation of Denis Edwards, pod in natural worlds. Theolog

Delio, I., 2020, 'Theology of nature or relational Holism? Building on Teilhard's vision', in T. Peters \& M. Turner (eds.), God in natural worlds. Theological explorations in appreciation of Denis Edwards, pp. 171-192, ATF, Adelaide.

Downs, S., 2020, 'Ecological theology: From dialogue to symposium', in T. Peters \& M. Turner (eds.), God in natural worlds. Theological explorations in appreciation of Denis Edwards, pp. 139-153, ATF, Adelaide.

Edwards, D., 2017, The natural world and God: Theological explorations, ATF, Adelaide.

Fowler, J.L., 2020, 'Deep incarnation and the real presence of Christ in the Lord Supper', in T. Peters \& M. Turner (eds.), God in natural worlds. Theological explorations in appreciation of Denis Edwards, pp. 193-210, ATF, Adelaide.

George, M., 2019, 'Is Eco-theologian Thomas Berry a Thomist?', Scientia et Fides 7(1), 47-71. https://doi.org/10.12775/SetF.2019.003

Gregersen, N.H., 2020, 'Is the universe a sacrament? Denis Edward's contribution to sacramental thinking', in T. Peters \& M. Turner (eds.), God in natural worlds. Theological explorations in appreciation of Denis Edwards, pp. 25-42, ATF, Adelaide.

Haught, J.F., 2020, 'Denis Edwards, Teilhard de Chardin, and Karl Rahner', in T. Peters \& M. Turner (eds.), God in natural worlds. Theological explorations in appreciation of Denis Edwards, pp. 157-170, ATF, Adelaide.

Jennings, B., 2019, 'Bioethics contra Biopower. Ecological humanism and flourishing life', in E. Parens \& J. Johnston (eds.), Human flourishing in an age of Gene editing pp. 247-266, OUP, Oxford.

Kelly, A.J., 2020, 'The Eucharist and Ecology', in T. Peters \& M. Turner (eds.), God in natural worlds. theological explorations in appreciation of Denis Edwards, pp. 211-224, ATF, Adelaide.

Lenow, J.E., 2020, 'Following the deeply incarnate Christ: Discipleship in the midst of environmental crisis', in T. Peters \& M. Turner (eds.), God in natural worlds. Theological explorations in appreciation of Denis Edwards, pp. 313-328, ATF, Adelaide.

Marcos, A. \& Perez, M., 2018, Meditación de la naturaleza humana, BAC, Madrid.

McGann, M.E., 2020, 'Eucharist: Longing for the Bread of Justice', in T. Peters \& M. Turner (eds.), God in natural worlds. Theological explorations in appreciation of Denis Edwards, pp. 225-240, ATF, Adelaide.

Milbank, J., 2006, Theology and social theory: Beyond Secular reason, 2nd edn., Willey, Oxford.

Nesteruk, A.V., 2020, 'Deep incarnation: From the hypostatic union to the universe in the image of the image', in T. Peters \& M. Turner (eds.), God in natural worlds. Theological explorations in appreciation of Denis Edwards, pp. 77-94, ATF, Adelaide.

Oleksowicz, M., 2020, 'Do we need a theology of science?', Cauriensia 15, 755-770. https://doi.org/10.17398/2340-4256.15.755

Peters, T., 2019, 'The Ebullient transhumanist and the Sober theologian', Scientia et Fides 7(2), 97-117. https://doi.org/10.12775/SetF.2019.018

Peters, T., 2020, 'Life in the Cosmos: Deep incarnation in deep space', in T. Peters \& M. Turner (eds.), God in natural worlds. Theological explorations in appreciation of Denis Edwards, pp. 107-138, ATF, Adelaide.

Peters, T. \& Turner, M., 2020a, God in the natural world. Theological explorations in appreciation of Denis Edwards, ATF, Adelaide.

Ritchie, S.L., 2017, 'Dancing around the causal joint: Challenging the theological turn in divine action theories', Zygon 52(2), 361-379. https://doi.org/10.1111/ zygo. 12336

Roszak, P., 2017, 'Pilgrimage as sacramentum peregrinationis? Discovering the Ecclesiological Background of the Camino de Santiago', in E. Alarcón \& P. Roszak (eds.), The way of St. James: renewing insights, pp. 137-157, Eunsa, Pamplona.

Roszak, P. \& Huzarek, T., 2019, 'Seeing God. Thomas Aquinas on Divine Presence in the world', Bogoslovni vestnik/Theological Quarterly 79(3), 739-749. https://doi. org/10.34291/BV2019/03/Roszak

Sanchez-Cañizares, J., 2019, Universo singular. Apuntes desde la fisica para una filosofia de la naturaleza, UFV, Madrid.

Sánchez-Palencia, A. \& Jordana-Butticaz, R., 2021, 'The origin of man in the light of three fields of knowledge: Science, philosophy and theology', Scripta Theologica 53(1), 9-45. https://doi.org/10.15581/006.53.1.9-45

Schoot, H., 2020, 'Thomas Aquinas on human beings as image of God', European Journal for the Study of Thomas Aquinas 38(1), 33-46. https://doi.org/10.2478/ ejsta-2020-0003

Strumiłowski, J.P., 2019, 'Complementarity and cohesion of the sophiologic and scientific vision of creation', Scientia et Fides 7(1), 207-225. https://doi. org/10.12775/SetF.2019.010

Trinidad, J., 2020,'Contributions of Walter Kasper's pneumatology to a theology of deep incarnation', in T. Peters \& M. Turner (eds.), God in natural worlds. Theological explorations in appreciation of Denis Edwards, pp. 263-280, ATF, Adelaide.

Worthing, M, 2020, 'Deep incarnation and the redemptive suffering of Christ for all creation', in T. Peters \& M. Turner (eds.), God in natural worlds. Theological explorations in appreciation of Denis Edwards, pp. 95-106, ATF, Adelaide. 